\title{
Clinical features of childhood diabetes mellitus focusing on latent autoimmune diabetes
}

\author{
Seung Ho Lee, MD, \\ Jeesuk Yu, MD, PhD
}

Department of Pediatrics, Dankook University Hospital, Cheonan, Korea
Received: 7 October, 2016

Revised: 26 October, 2016

Accepted: 30 November, 2016

Address for correspondence: Jeesuk Yu, MD, PhD

Department of Pediatrics, Dankook University Hospital, Dankook University College of Medicine, 201 Manghyang-ro, Dongnam-gu, Cheonan, Choongnam 31116, Korea Tel: +82-41-550-6590

Fax: +82-41-565-6167

E-mail:dryujs@dankook.ac.kr

http://orcid.org/0000-0003-00202000
Purpose: This study was designed to evaluate the clinical characteristics of childhood diabetes mellitus (DM) according to its classification as well as the clinical course of latent autoimmune diabetes (LAD) that initially showed noninsulin dependence despite autoantibody positivity.

Methods: A total of 91 subjects diagnosed between 2001 and 2015 were enrolled in the study. They were classified into 3 groups: type 1 DM, LAD, and type 2 DM. Clinical features and laboratory findings were compared among groups.

Results: Among 91 subjects, type 1 DM, LAD, and type 2 DM were 51 (56.0\%), 7 (7.7\%), and 33 (36.3\%), respectively. In LAD, age at diagnosis and BMI Z-scores were higher, as compared with those in type $1 \mathrm{DM}$. Initial serum c-peptide levels were higher in LAD than those in type $1 \mathrm{DM}$, but lower than those in type $2 \mathrm{DM}$. In LAD, the mean follow-up duration was 4.56 years, and $43 \%$ of the patients ultimately required intensive insulin treatment with dosage of $>0.5 \mathrm{U} / \mathrm{kg} /$ day. $\mathrm{HbA} 1 \mathrm{C}$ and serum c-peptide levels at the time of intensive insulin treatment were $9.43 \pm 0.93 \%$ and $1.37 \pm 1.36 \mathrm{ng} / \mathrm{mL}$, respectively. Recent serum c-peptide/glucose ratio was lower in the group requiring intensive insulin treatment than the group without intensive insulin treatment, with $P$-value of $0.057(0.003 \pm 0.005$ vs. $0.071 \pm 0.086)$.

Conclusion: Initial autoantibody evaluation is useful for classification and management. Close monitoring of the patients with LAD is important due to the expected need for intensive insulin treatment within several years.

Keywords: Type 2 diabetes mellitus, Autoantibody, Child

\section{Introduction}

Diabetes mellitus (DM) is classified into either a type 1 DM caused by destruction of beta cell of pancreas or a type 2 DM resulting from insulin resistance and relative insulin deficiency. Previously, most childhood DM patients belong to type 1, but recently there has been a dramatic increase of type $2 \mathrm{DM}^{1-5)}$. However, it is sometimes not easy to classify DM based on clinical features. There is an increasing tendency of several cases presenting with noninsulin dependence despite autoantibody positivity at the time of diagnosis i.e., type 1.5 DM, latent autoimmune diabetes (LAD) in youth, slowly progressive type $1 \mathrm{DM}$, or youth onset diabetes of maturity ${ }^{6}$. LAD patients had older age of disease onset, and their blood glucose was well controlled without insulin injection at the time of diagnosis, but can eventually progressed into insulin dependence within several years. This study was designed to evaluate the clinical characteristics of childhood DM according to classification as well as the clinical course of LAD that initially showed non-insulin dependence despite autoantibody positivity.

\section{Materials and methods}

This study was designed as a cross-sectional study. A total of 91 subjects who were diagnosed 
with DM and could be followed up at Dankook University Hospital, Cheonan, Korea between 2001 and 2015 were enrolled in the study. The subjects with fulminant diabetes, $<6$ months of follow-up, no assessment of the autoantibody status at disease onset, or weakly positive autoantibody that became negative during follow-up were excluded. Subjects were classified into 3 groups: type $1 \mathrm{DM}$, LAD, and type $2 \mathrm{DM}$. Type $1 \mathrm{DM}$ group included patients who needed absolute insulin treatment for survival either in the presence of one or more autoantibody positivity or whose initial serum c-peptide level was lower than $0.6 \mathrm{ng} / \mathrm{mL}^{7)}$. Type $2 \mathrm{DM}$ group included patients with no autoantibody positivity as well as no requirement of absolute insulin treatment. LAD group included patients with initial autoantibody positivity without absolute insulin requirement for survival initially or within several months after the diagnosis. The definition of LAD was originated and modified from the diagnosis of latent autoimmune diabetes in adult (LADA) $)^{8)}$. Clinical characteristics such as age at diagnosis, follow-up duration, body mass index (BMI) Z-score, initial presence of diabetic ketoacidosis (DKA), and treatment modality were reviewed. Laboratory findings such as autoantibody status, hemoglobin Alc (HbAlc), fructosamine, serum c-peptide, and serum c-peptide/glucose ratio as well as clinical characteristics were compared among groups. Autoantibodies evaluated in the study included anti-glutamic acid decarboxylase (GAD) autoantibody using immunoradiometric assay (Immunotech, Marseille, France), anti-insulin autoantibody using enzyme immunoassay (Orgentec Diagnostika GmbH, Mainz, Germany), anti-islet cell autoantibody using indirect fluorescent assay (SCIMEDX, Denville, NJ, USA), and antityrosine phosphatase insulinoma-associated 2 (IA-2) autoantibody using radioimmunoassay (RSR limited, Cardiff, UK). In LAD, laboratory findings including autoantibody status, $\mathrm{HbAlc}$, serum c-peptide levels and change of treatment modality were monitored during follow-up. In this study, we defined intensive insulin treatment as insulin injection of more than 3 times a day to control blood glucose. BMI Z-scores were derived from LMS values presented by 2007 Korean Growth Normogram ${ }^{9}$. The LMS parameters are the power in the Box-Cox transformation $(\mathrm{L})$, the median $(\mathrm{M})$, and the generalized coefficient of variation (S).

Mann-Whitney $U$-test, Kruskal-Wallis test, and chi-square test were used for statistics using IBM SPSS Statistics ver. 20.0 (IBM Co., Armonk, NY, USA). A $P$-value of $<0.05$ was

Table 1. Clinical and laboratory characteristics of the study subjects

\begin{tabular}{|c|c|c|c|c|c|c|}
\hline \multirow{2}{*}{ Variable } & \multirow{2}{*}{ Type 1} & \multirow{2}{*}{ LAD } & \multirow{2}{*}{ Type 2} & \multicolumn{3}{|c|}{$P$-value } \\
\hline & & & & Among groups & LAD vs. type 1 & LAD vs. type 2 \\
\hline Total $(n=91)$ & $51(56.0)$ & $7(7.7)$ & $33(36.3)$ & & & \\
\hline \multicolumn{7}{|l|}{ Sex } \\
\hline Male & $25(49.0)$ & $7(100.0)$ & $15(45.5)$ & $0.027^{*}$ & $0.013^{*}$ & $0.011^{*}$ \\
\hline Female & $26(51.0)$ & $0(0.0)$ & $18(54.5)$ & & & \\
\hline Age at diagnosis (yr) & $8.61 \pm 4.16$ & $13.18 \pm 3.42$ & $13.59 \pm 2.49$ & $<0.001^{*}$ & $<0.009^{*}$ & 0.917 \\
\hline Follow-up duration (yr) & $4.45 \pm 3.27$ & $4.56 \pm 3.76$ & $3.12 \pm 2.79$ & 0.149 & 0.834 & 0.344 \\
\hline \multicolumn{7}{|l|}{ DKA at diagnosis $(n=89)$} \\
\hline Present & $35(70.0)$ & $1(14.3)$ & $2(6.2)$ & $<0.001^{*}$ & $0.008^{*}$ & 0.457 \\
\hline Absent & $15(30.0)$ & $6(85.7)$ & $30(93.8)$ & & & \\
\hline BMI Z-score at diagnosis $(n=83)$ & $-1.21 \pm 1.47$ & $0.78 \pm 0.91$ & $0.91 \pm 1.51$ & $<0.001^{*}$ & $0.001^{*}$ & 0.416 \\
\hline Initial glucose (mg/dL) ( $\mathrm{n}=87)$ & $461.89 \pm 202.89$ & $298.71 \pm 140.30$ & $270.66 \pm 137.65$ & $<0.001^{*}$ & $0.035^{*}$ & 0.654 \\
\hline $\mathrm{HbA} 1 \mathrm{C}$ at diagnosis $(\%)(\mathrm{n}=88)$ & $12.54 \pm 2.01$ & $11.51 \pm 2.34$ & $11.64 \pm 2.79$ & 0.258 & 0.354 & 0.900 \\
\hline Fructosamine at diagnosis $(\mu \mathrm{mol} / \mathrm{L})(\mathrm{n}=42)$ & $639.28 \pm 188.05$ & $579.0 \pm 119.03$ & $462.14 \pm 210.98$ & $0.009^{*}$ & 0.471 & 0.271 \\
\hline Initial serum c-peptide (ng/mL) (n=88) & $0.52 \pm 0.45$ & $1.92 \pm 1.07$ & $3.62 \pm 2.02$ & $<0.001^{*}$ & $0.002^{*}$ & $0.049^{*}$ \\
\hline Serum c-peptide/glucose ratio $(n=84)$ & $0.001 \pm 0.002$ & $0.009 \pm 0.012$ & $0.017 \pm 0.019$ & $<0.001^{*}$ & $0.001^{*}$ & 0.128 \\
\hline $\mathrm{pH}$ at diagnosis $(\mathrm{n}=62)$ & $7.23 \pm 0.16$ & $7.38 \pm 0.11$ & $7.38 \pm 0.03$ & $0.003^{*}$ & 0.114 & 0.654 \\
\hline Number of autoantibody & $1.63 \pm 0.63$ & $2.0 \pm 0.82$ & $0 \pm 0$ & $<0.001^{*}$ & 0.301 & $<0.001^{*}$ \\
\hline GAD Ab titer $(\mathrm{U} / \mathrm{mL})(\mathrm{n}=79)$ & $42.97 \pm 83.82$ & $63.19 \pm 118.07$ & $0.36 \pm 0.23$ & $<0.001^{*}$ & 0.787 & $0.002^{*}$ \\
\hline Insulin Ab titer (U/mL) $(n=71)$ & $6.95 \pm 11.02$ & $11.8 \pm 14.06$ & $1.79 \pm 1.63$ & $0.027^{*}$ & 0.546 & 0.089 \\
\hline IA-2 Ab titer $(\mathrm{U} / \mathrm{mL})(\mathrm{n}=62)$ & $36.95 \pm 120.66$ & $8.5 \pm 10.97$ & $0.39 \pm 0.08$ & $<0.001^{*}$ & 0.857 & $0.011^{*}$ \\
\hline \multicolumn{7}{|l|}{ Initial treatment $(\mathrm{n}=92)$} \\
\hline None & $0(0)$ & $0(0)$ & $1(3.0)$ & $<0.001^{*}$ & $<0.001^{*}$ & 0.483 \\
\hline Insulin only & $51(100.0)$ & $2(28.6)$ & $5(15.2)$ & & & \\
\hline Insulin and $\mathrm{OHA}$ & $0(0)$ & $3(42.9)$ & $8(24.2)$ & & & \\
\hline OHA only & $0(0)$ & $2(28.6)$ & $19(57.6)$ & & & \\
\hline
\end{tabular}

Values are presented as number (\%) or mean \pm standard deviation.

$\mathrm{LAD}$, latent autoimmune diabetes; DKA, diabetic ketoacidosis; BMI, body mass index; GAD, glutamic acid decarboxylase; IA-2, insulinomaassociated 2; HbA1c, hemoglobin A1c; OHA, oral hypoglycemic agent.

${ }^{*} P<0.05$. 
considered statistically significant.

The study was approved by the Institutional Review Board of Dankook University Hospital (DKUH 2016-02-018).

\section{Results}

\section{Demographics and characteristics of the study subjects}

Ninety-one patients were included in the study. Among these, 47 were males and 44 were females. The mean age at diagnosis of all subjects was $10.76 \pm 4.32$ years, and mean follow-up duration was $3.92 \pm 3.08$ years. Among all patients, 38 (41.8\%) presented DKA at diagnosis. At diagnosis, HbAlc was $12.13 \pm 2.37 \%$, and fructosamine was $559.03 \pm 194.98 \mu \mathrm{mol} / \mathrm{L}$. Initial glucose was $378.43 \pm 198.56 \mathrm{mg} / \mathrm{dL}$, initial serum c-peptide was $1.72 \pm 1.92$ $\mathrm{ng} / \mathrm{mL}$, and serum c-peptide/glucose ratio was $0.008 \pm 0.014$.

\section{Comparison between the groups subdivided by the type of DM}

Among 91 subjects, type $1 \mathrm{DM}$, LAD, and type $2 \mathrm{DM}$ were $51(56.0 \%), 7(7.7 \%)$, and $33(36.3 \%)$, respectively (Table 1). Age at diagnosis and BMI $Z$-scores were lower (age at diagnosis $8.61 \pm 4.16$ years vs. $13.18 \pm 3.42$ years vs. $13.59 \pm 2.49$ years, respectively $P<0.001$; BMI $Z$-scores $-1.21 \pm 1.47$ vs. $0.78 \pm 0.91$ vs. $0.91 \pm 1.51$, respectively, $P<0.001$ ), and DKA was more common (70\% vs. $14.3 \%$ vs. $6.2 \%$, respectively, $P<0.001$ ) at disease onset in type $1 \mathrm{DM}$ than in other 2 groups. Serum c-peptide levels and serum c-peptide/glucose ratio were lowest in type 1 DM (serum c-peptide $0.52 \pm 0.45 \mathrm{ng} / \mathrm{mL}$ vs. $1.92 \pm 1.07 \mathrm{ng} / \mathrm{mL}$ vs. $3.62 \pm 2.02$ $\mathrm{ng} / \mathrm{mL}$, respectively, $P<0.001$; serum c-peptide/glucose ratio $0.001 \pm 0.002$ vs. $0.009 \pm 0.012$ vs. $0.017 \pm 0.019$, respectively, $P<0.001$ ), and fructosamine levels at diagnosis were highest in type $1 \mathrm{DM}(639.28 \pm 188.05 \mu \mathrm{mol} / \mathrm{L}$ vs. $579.0 \pm 119.03 \mu \mathrm{mol} /$
L vs. $462.14 \pm 210.98 \mu \mathrm{mol} / \mathrm{L}$, respectively, $P=0.009)$. HbAlc at diagnosis showed no significant difference among groups subdivided by the type of DM. Autoantibody positivity was $96 \%$ in type $1 \mathrm{DM}$, with GAD autoantibody as most common (Fig. 1). The positivity of each autoantibody in type $1 \mathrm{DM}$ showed no significant difference when compared by age at onset. At diagnosis, fructosamine levels showed a significant difference between type $1 \mathrm{DM}$ and type $2 \mathrm{DM}(639.28 \pm 188.05 \mu \mathrm{mol} /$ L vs. $462.14 \pm 210.98 \mu \mathrm{mol} / \mathrm{L}$, respectively, $P=0.003)$, but they had no significant difference between type $1 \mathrm{DM}$ and LAD $(639.28 \pm 188.05 \mu \mathrm{mol} / \mathrm{L}$ vs. $579.0 \pm 119.03 \mu \mathrm{mol} / \mathrm{L}$, respectively, $P=0.471)$.

\section{Percentage and titers of autoantibody positivity according to type of DM}

Among patients with type 1 DM, 10 patients (19.6\%) had only GAD autoantibody, and 5 patients (9.8\%) and 2 patients (3.9\%) had only insulin autoantibody and IA-2 autoantibody, respectively (Fig. 1). Twelve patients (23.5\%) had GAD and insulin autoantibodies and 18 patients (35.3\%) had GAD and IA-2 autoantibodies. Two patients had 3 autoantibodies, of these, 1 had GAD, insulin and IA-2 autoantibodies and the other had GAD, islet cell and IA-2 autoantibodies. Among patients with LAD, 2 (28.6\%) had only insulin autoantibody, 3 (42.9\%) had 2 autoantibodies ( 1 had GAD and IA-2 autoantibodies and others had GAD and insulin autoantibodies). Two patients with LAD had 3 autoantibodies including GAD, islet cell and IA-2 autoantibodies. Percentage and titers of each autoantibody showed no significant difference between type 1 and LAD.

\section{Clinical and laboratory findings of $L A D$}

Seven patients were classified into LAD (7.7\%), and their mean follow-up duration was 4.56 years. Three patients

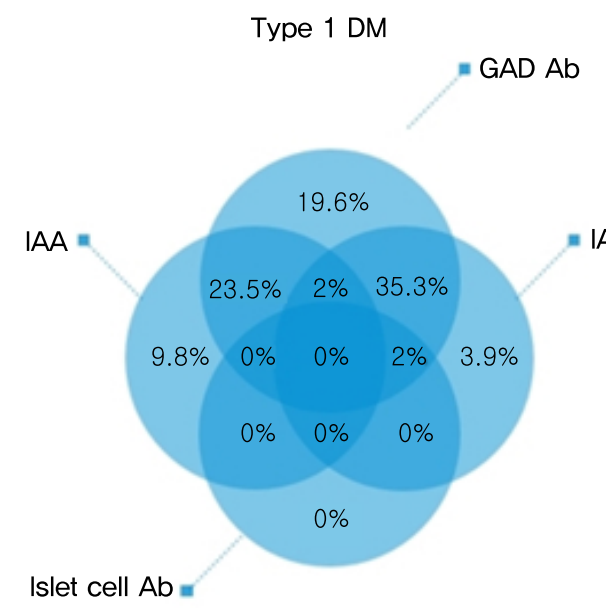

Latent autoimmune diabetes

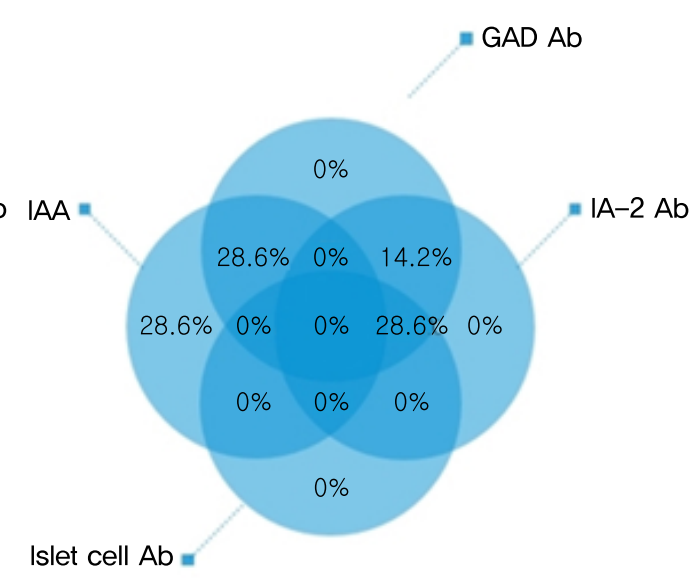

Fig. 1. Venn diagrams show distribution of autoantibody in type 1 diabetes mellitus (DM) and latent autoimmune diabetes. IAA, Insulin autoantibody; IA-2, insulinoma-associated 2; GAD, glutamic acid decarboxylase; Ab, antibody. 
(42.9\%) required intensive insulin treatment during follow-up (Table 2), and their mean duration from diagnosis to intensive insulin treatment was 3.67 years. $\mathrm{HbAlC}$ and serum c-peptide levels at the time of initiation of intensive insulin treatment were $9.43 \pm 0.93 \%$ and $1.37 \pm 1.36 \mathrm{ng} / \mathrm{mL}$, respectively. Age at diagnosis, initial BMI Z-score, HbAlc, serum c-peptide, and serum c-peptide/glucose ratio showed no significant difference between with and without intensive insulin treatment groups. However, recent serum c-peptide/glucose ratio was lower in the group with intensive insulin treatment $(0.003 \pm 0.005$ vs.

Change of $\mathrm{HbA1c}$ in LAD

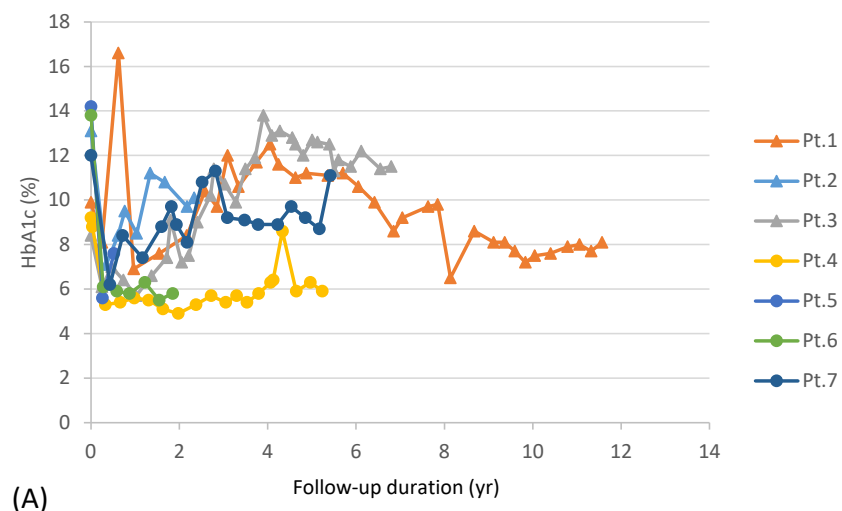

$0.071 \pm 0.086, P=0.057$ ), without statistical significance. LAD patients showed increasing trend of $\mathrm{HbAlc}$, and decreasing trend of serum c-peptide during follow-up (Fig. 2).

\section{Discussion}

DM is one of the most common chronic metabolic diseases in children and adolescents. Childhood DM can be classified into either a type $1 \mathrm{DM}$ that is characterized by insulin deficiency due to pancreatic beta cell damage or a type 2 DM

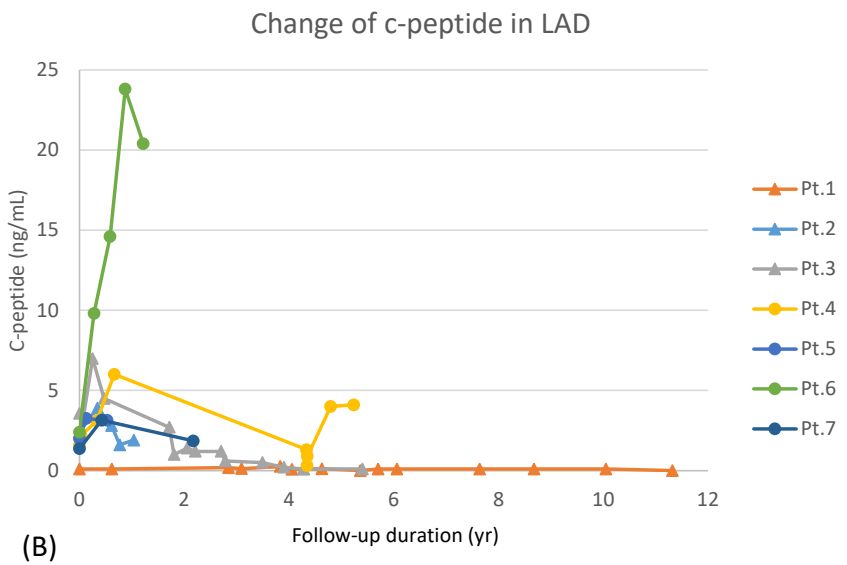

Fig. 2. Latent autoimmune diabetes (LAD) patients show increasing trend of hemoglobin $A 1 \mathrm{c}(\mathrm{HbA} \mathrm{Ac})(\mathrm{A})$, and decreasing trend of serum c-peptide (B) during follow-up. Pt., patient.

Table 2. Clinical and laboratory characteristics and follow-up data of patients with latent autoimmune diabetes

\begin{tabular}{|c|c|c|c|c|c|c|c|c|c|c|}
\hline \multirow{2}{*}{ Variable } & \multicolumn{4}{|c|}{ Group 1} & \multicolumn{5}{|c|}{ Group 2} & \multirow{2}{*}{$P$-value } \\
\hline & Pt. 1 & Pt. 2 & Pt. 3 & Mean $\pm S D$ & Pt. 4 & Pt. 5 & Pt. 6 & Pt. 7 & Mean $\pm S D$ & \\
\hline Sex & $M$ & $M$ & $M$ & & M & M & $M$ & $M$ & & \\
\hline Age at diagnosis (yr) & 14.2 & 14.49 & 8.49 & $12.39 \pm 3.16$ & 9.03 & 18.32 & 14.55 & 13.2 & $13.78 \pm 3.83$ & 0.629 \\
\hline Initial BMI Z-score & 0.49 & 0.82 & 1.11 & $0.81 \pm 0.31$ & 2.64 & 0.003 & 0.05 & 0.04 & $0.77 \pm 1.26$ & 0.400 \\
\hline Initial HbA1c (\%) & 9.9 & 13.1 & 8.4 & $10.47 \pm 2.4$ & 9.2 & 14.2 & 13.8 & 12 & $12.3 \pm 2.28$ & 0.400 \\
\hline Initial serum c-peptide & 0.1 & 2.4 & 3.57 & $2.02 \pm 1.77$ & 1.6 & 2 & 2.4 & 1.36 & $1.84 \pm 0.46$ & 0.629 \\
\hline Initial serum c-peptide/glucose ratio & 0.005 & 0.011 & 0.0357 & $0.02 \pm 0.02$ & 0.003 & 0.0057 & 0.0084 & 0.0034 & $0.005 \pm 0.002$ & 0.629 \\
\hline GAD Ab & - & + & + & & + & + & - & + & & \\
\hline Islet cell Ab & $\mathrm{N} / \mathrm{A}$ & + & + & & - & - & - & N/A & & \\
\hline Insulin Ab & + & - & - & & - & + & + & + & & \\
\hline $\mathrm{IA}-2 \mathrm{Ab}$ & N/A & + & + & & + & N/A & - & N/A & & \\
\hline Follow-up duration (yr) & 11.68 & 1.36 & 6.09 & $6.38 \pm 5.17$ & 4.38 & 0.91 & 1.88 & 5.66 & $3.21 \pm 2.19$ & 0.400 \\
\hline Initial treatment & Insulin & Met+LI & Met & & Met & Met+LI & Met+LI & Insulin & & \\
\hline Recent treatment & IIT & IIT & $\| T$ & & Met & Met+LI & Met & Met+Gmp+LI & & \\
\hline Time to insulin treatment (yr) & 7.64 & 0.66 & 2.7 & $3.67 \pm 3.59$ & & & & & & \\
\hline $\mathrm{HbA} 1 \mathrm{c}$ at insulin treatment (\%) & 9.7 & 8.4 & 10.2 & $9.43 \pm 0.93$ & & & & & & \\
\hline $\begin{array}{l}\text { Serum c-peptide } \\
\text { at insulin treatment (ng/mL) }\end{array}$ & 0.1 & 2.8 & 1.2 & $1.37 \pm 1.36$ & & & & & & \\
\hline $\begin{array}{l}\text { Serum c-peptide/glucose ratio } \\
\text { at insulin treatment }\end{array}$ & 0.0004 & 0.0156 & 0.0039 & $0.007 \pm 0.008$ & & & & & & \\
\hline Recent $\mathrm{HbA1c}$ & 8.1 & 10.1 & 11.5 & $9.9 \pm 1.71$ & 5.9 & 7.6 & 5.8 & 11.1 & $7.6 \pm 2.48$ & 0.229 \\
\hline Recent serum c-peptide & 0.1 & 1.9 & 0.1 & $0.7 \pm 1.04$ & 4.1 & 3.13 & 20.4 & 1.85 & $7.37 \pm 8.74$ & 0.114 \\
\hline Recent serum c-peptide/glucose ratio & 0.0004 & 0.0083 & 0.0003 & $0.003 \pm 0.005$ & 0.0339 & 0.0237 & 0.2 & 0.0253 & $0.071 \pm 0.086$ & 0.057 \\
\hline
\end{tabular}

Pt., patient; BMI, body mass index; HbA1c, hemoglobin A1c; GAD, glutamic acid decarboxylase; Ab, antibody; IA-2, insulinoma-associated 2; Met, metformin; Gmp, glimepiride; LI, long acting insulin; IIT, intensive insulin treatment; N/A, not assessed. 
that is characterized by insulin resistance at the level of skeletal muscle, liver, and adipose tissue combined with various degrees of beta cell impairment ${ }^{10)}$. Recently, the prevalence of both type 1 and type 2 DM in children has been increasing, with a dramatic increase in type $2 \mathrm{DM}^{1-5,11)}$. Type $2 \mathrm{DM}$ patients typically have clinical features characterized by older age of onset, high BMI, low prevalence of diabetes ketoacidosis and presence of signs of insulin resistance (hypertension, acanthosis nigricans), as compared with type $1 \mathrm{DM}$ patients ${ }^{4,12,13}$. However, it is sometimes difficult to classify the case with type 2 clinical phenotype despite the presence of autoantibody, therefore it is usually designated as $\mathrm{LAD}^{14)}$.

Several previous studies on LAD in adults described the condition as $\mathrm{LADA}^{6,15,16)}$ or slowly progressive insulin dependent $\mathrm{DM}^{177}$.

The diagnosis of LADA was established if following criteria were satisfied: (1) the onset was more than 35 years of age, (2) any circulating islet cell specific autoantibody was detected, (3) insulin therapy was not indicated in the first 6 months after the diagnosis ${ }^{8}$. Because our study subjects were children and adolescents, we defined LAD as DM patients who did not require absolute insulin treatment for survival initially or within several months after the diagnosis despite autoantibody positivity. The prevalence of LADA was estimated at $2 \%-12 \%$ of all cases of diabetes ${ }^{6}$. In 2005, Palmer et al. ${ }^{15}$ reported that LADA patients commonly have reactive $\mathrm{T}$ cells to islet antigens and share many genetic similarities with type $1 \mathrm{DM}$, therefore LADA is an autoimmune disease like type 1 DM. However, a recent study on LADA indicated that LADA shows intermediate features between type 2 and type 1 diabetes, and a gradual decline in autoantibody titer in LADA subjects requiring insulin within the first year from diagnosis, as compared to subjects not requiring insulin after 10 years of follow-up ${ }^{18)}$. A pediatric population study showed $9.8 \%$ of subjects with clinical type 2 diabetes were autoantibody positive, and had evidence of insulin deficiency due to islet autoimmunity ${ }^{19)}$.

In this study, 7 patients had LAD, defined as type 2 clinical phenotype and autoantibody positivity at the onset of DM. In general, patients diagnosed as LAD or slowly progressive type $1 \mathrm{DM}$ progressed to insulin deficiency and became insulin dependent DM. In our study, LAD patients had similar clinical and laboratory features as type 2 DM patients except autoantibody positivity, male predominance, and lower initial serum c- peptide. Among the LAD patients, 3 patients needed absolute intensive insulin treatment and were treated by multiple insulin injection therapy; another 2 patients could be managed by long acting basal insulin with oral hypoglycemic agent; and the remaining 2 patients were treated only by oral hypoglycemic agents during follow-up. In LAD, age at diagnosis, BMI Z-score, and initial and recent c-peptide/glucose ratio showed no significant differences between the group with intensive insulin treatment and the group without intensive insulin treatment, possibly due to the small number of patients included in this study. Recent serum c-peptide/glucose ratio was lower in the group with intensive insulin treatment $(0.003 \pm 0.005$ vs. $0.071 \pm 0.086, P=0.057)$, although it was not statistically significant.

Cho et el ${ }^{20)}$ reported that if the c-peptide level is $<0.6 \mathrm{ng} /$ $\mathrm{mL}$ at diagnosis, type $2 \mathrm{DM}$ can be excluded; in addition, if c-peptide level is $>3.0 \mathrm{ng} / \mathrm{mL}$, a type $1 \mathrm{DM}$ diagnosis is unlikely. However, one case with $\mathrm{LAD}$ required intensive insulin treatment during follow-up despite initial c-peptide level of $3.57 \mathrm{ng} /$ $\mathrm{mL}$. Therefore, it is considered that regular evaluation of serum c-peptide is important in patients with LAD.

Lohmann et el. ${ }^{21)}$ reported that among LADA patients, those with multiple autoantibodies have the same features as patients with type 1 diabetes; and the combination of islet cell antibodies and GAD antibodies and high titer of GAD antibodies are characteristic of patients with insulin deficiency with the clinical features of type 1 diabetes. However, LAD patients included in our study showed no significant differences in autoantibody titer and the number of autoantibody between with and without intensive insulin treatment groups, possibly due to the small number of patients included and lack of assessment of the status of some autoantibodies.

Determining when to start insulin treatment in LAD or type 2 DM patients is difficult. Previous reports have indicated predictors of subsequent insulin treatment requirement in patients with type 2 diabetes ${ }^{22,23}$. Saisho et el. ${ }^{23)}$ reported that postprandial serum c-peptide to plasma glucose ratio is the best predictive marker for future insulin therapy and the best cutoff value was 0.0202 with $80.8 \%$ sensitivity and $63.3 \%$ specificity. In our study, LAD patients with intensive insulin treatment showed below 0.0202 serum c-peptide to plasma glucose ratio at start of insulin treatment, whereas, group with no intensive insulin treatment showed above 0.0202 serum c-peptide to plasma glucose ratio.

Several recent studies have focused on markers of long-term endogenous insulin production in patients with DM. Sonoda et el. ${ }^{24)}$ reported that insulin secretion and resistance strongly influences fasting plasma c-peptide, and insulin secretion affects 24 -hour pooled urine c-peptide in type $2 \mathrm{DM}$. Hope et $\mathrm{al}^{25)}$ reported time to insulin and age at diagnosis were the best predictors of long-term insulin production. But in our study, we were unable to identify predictors of intensive insulin treatment in patients with LAD or type $2 \mathrm{DM}$.

All LAD patients were male with significant differences, as compared with type 1 or type 2 patients. This might be attributed to small number of study subjects, and further study will be required to ensure that the male gender is actually predominant in LAD.

DM is an established risk factor for microvascular disease like nephropathy, retinopathy, neuropathy leading to end-stage renal disease, loss of visual acuity, limb amputations ${ }^{26)}$, and macrovascular disease like atherosclerosis ${ }^{27}$ leading to coronary heart disease, myocardial infarction or ischemic stroke ${ }^{28)}$. DM is associated with substantial premature death from vascular diseases, several cancers and infectious disease ${ }^{29)}$. Patients with DM also have higher risk of psychiatric disorder like depression, anxiety, or eating disorder ${ }^{30,31)}$. All of these complications 
contribute to the excess morbidity and mortality in patients with diabetes. Therefore, control of blood sugar level is important in patients with DM. In LAD patients, insulin treatment is likely to be necessary within several years, therefore it is important to distinguish LAD patients who need insulin treatment from type 2 DM patients.

This study has several limitations. First, the number of patients classified into LAD in the study was small. Second, we could not analyze some factors that might show characteristics of LAD such as family history and urine c-peptide levels.

In conclusion, evaluation of autoantibody levels in patients with DM is important for classification and management. Reevaluation of autoantibody levels may be necessary in patients with initial weakly positive autoantibody titer in the presence of type 2 DM phenotype. It is important to closely monitor patients with positive autoantibody and clinical features of type 2 DM due to the expected need for intensive insulin treatment within several years.

\section{Conflict of interest}

No potential conflict of interest relevant to this article was reported.

\section{Acknowledgments}

The present research was conducted by the research fund of Dankook University in 2015.

\section{References}

1. Boehme MW, Buechele G, Frankenhauser-Mannuss J, Mueller J, Lump D, Boehm BO, et al. Prevalence, incidence and concomitant co-morbidities of type 2 diabetes mellitus in South Western Germany: a retrospective cohort and case control study in claims data of a large statutory health insurance. BMC Public Health 2015;15:855.

2. D'Adamo E, Caprio S. Type 2 diabetes in youth: epidemiology and pathophysiology. Diabetes Care 2011;34 Suppl 2:S161-5.

3. Dabelea D, Mayer-Davis EJ, Saydah S, Imperatore G, Linder B, Divers J, et al. Prevalence of type 1 and type 2 diabetes among children and adolescents from 2001 to 2009. JAMA 2014;311:1778-86.

4. Reinehr T. Type 2 diabetes mellitus in children and adolescents. World J Diabetes 2013;4:270-81.

5. Chen L, Magliano DJ, Zimmet PZ. The worldwide epidemiology of type 2 diabetes mellitus--present and future perspectives. Nat Rev Endocrinol 2011;8:228-36.

6. Nambam B, Aggarwal S, Jain A. Latent autoimmune diabetes in adults: A distinct but heterogeneous clinical entity. World J Diabetes 2010;1:111-5.

7. Jones AG, Hattersley AT. The clinical utility of C-peptide measurement in the care of patients with diabetes. Diabet Med 2013;30:803-17.

8. Hosszúfalusi N, Vatay A, Rajczy K, Prohászka Z, Pozsonyi E, Horváth L, et al. Similar genetic features and different islet cell autoantibody pattern of latent autoimmune diabetes in adults (LADA) compared with adult-onset type 1 diabetes with rapid progression. Diabetes Care 2003;26:452-7.

9. Moon JS, Lee SY, Nam CM, Choi JM, Choe BK, Seo JW, et al. 2007 Korean National Growth Charts: review of developmental process and an outlook. Korean J Pediatr 2008;51:1-25.

10. Kliegman RM, Stanton BF, St Geme JW, Schor NF, Behrman RE. Nelson textbook of pediatrics. 20th ed. Philadelphia (PA): Elsevier, 2016.

11. Hu FB. Globalization of diabetes: the role of diet, lifestyle, and genes. Diabetes Care 2011;34:1249-57.

12. Rao PV. Type 2 diabetes in children: clinical aspects and risk factors. Indian J Endocrinol Metab 2015;19(Suppl 1):S47-50.

13. Rosenbloom AL, Silverstein JH, Amemiya S, Zeitler P, Klingensmith GJ. Type 2 diabetes in children and adolescents. Pediatr Diabetes 2009;10 Suppl 12:17-32.

14. Naik RG, Palmer JP. Latent autoimmune diabetes in adults (LADA). Rev Endocr Metab Disord 2003;4:233-41.

15. Palmer JP, Hampe CS, Chiu H, Goel A, Brooks-Worrell BM. Is latent autoimmune diabetes in adults distinct from type 1 diabetes or just type 1 diabetes at an older age? Diabetes 2005;54 Suppl 2:S62-7.

16. Pipi E, Marketou M, Tsirogianni A. Distinct clinical and laboratory characteristics of latent autoimmune diabetes in adults in relation to type 1 and type 2 diabetes mellitus. World J Diabetes 2014;5:505-10.

17. Kobayashi T, Tamemoto K, Nakanishi K, Kato N, Okubo M, Kajio $\mathrm{H}$, et al. Immunogenetic and clinical characterization of slowly progressive IDDM. Diabetes Care 1993;16:780-8.

18. Maddaloni E, Lessan N, Al Tikriti A, Buzzetti R, Pozzilli P, Barakat MT. Latent autoimmune diabetes in adults in the United Arab Emirates: clinical features and factors related to insulin-requirement. PLoS One 2015;10:e0131837.

19. Klingensmith GJ, Pyle L, Arslanian S, Copeland KC, Cuttler L, Kaufman F, et al. The presence of GAD and IA-2 antibodies in youth with a type 2 diabetes phenotype: results from the TODAY study. Diabetes Care 2010;33:1970-5

20. Cho MJ, Kim MS, Kim CJ, Kim EY, Kim JD, Kim EY, et al. Fasting serum C-peptide is useful for initial classification of diabetes mellitus in children and adolescents. Ann Pediatr Endocrinol Metab 2014;19:80-5.

21. Lohmann T, Kellner K, Verlohren HJ, Krug J, Steindorf J, Scherbaum WA, et al. Titre and combination of ICA and autoantibodies to glutamic acid decarboxylase discriminate two clinically distinct types of latent autoimmune diabetes in adults (LADA). Diabetologia 2001;44:1005-10.

22. Ludvigsson J, Carlsson A, Forsander G, Ivarsson S, Kockum I, Lernmark A, et al. C-peptide in the classification of 
diabetes in children and adolescents. Pediatr Diabetes 2012;13:45-50.

23. Saisho Y, Kou K, Tanaka K, Abe T, Kurosawa H, Shimada A, et al. Postprandial serum C-peptide to plasma glucose ratio as a predictor of subsequent insulin treatment in patients with type 2 diabetes. Endocr J 2011;58:315-22.

24. Sonoda R, Tanaka K, Kikuchi T, Onishi Y, Takao T, Tahara $\mathrm{T}$, et al. C-peptide level in fasting plasma and pooled urine predicts $\mathrm{HbAlc}$ after hospitalization in patients with type 2 diabetes mellitus. PLoS One 2016;11:e0147303.

25. Hope SV, Wienand-Barnett S, Shepherd M, King SM, Fox C, Khunti K, et al. Practical Classification Guidelines for Diabetes in patients treated with insulin: a cross-sectional study of the accuracy of diabetes diagnosis. Br J Gen Pract 2016;66:e315-22.

26. Fowler MJ. Microvascular and macrovascular complications of diabetes. Clin Diabetes 2008;26:77-82.

27. Boyle PJ. Diabetes mellitus and macrovascular disease: mechanisms and mediators. Am J Med 2007;120(9 Suppl 2):S12-7.

28. Emerging Risk Factors Collaboration, Sarwar N, Gao P, Seshasai SR, Gobin R, Kaptoge S, et al. Diabetes mellitus, fasting blood glucose concentration, and risk of vascular disease: a collaborative meta-analysis of 102 prospective studies. Lancet 2010;375:2215-22.

29. Emerging Risk Factors Collaboration, Seshasai SR, Kaptoge S, Thompson A, Di Angelantonio E, Gao P, et al. Diabetes mellitus, fasting glucose, and risk of cause-specific death. $\mathrm{N}$ Engl J Med 2011;364:829-41.

30. Butwicka A, Frisén L, Almqvist C, Zethelius B, Lichtenstein P. Risks of psychiatric disorders and suicide attempts in children and adolescents with type 1 diabetes: a populationbased cohort study. Diabetes Care 2015;38:453-9.

31. Ducat L, Rubenstein A, Philipson LH, Anderson BJ. A review of the mental health issues of diabetes conference. Diabetes Care 2015;38:333-8. 